\title{
REVIEW
}

\section{Truncated and modified amyloid-beta species}

\author{
Markus P Kummer ${ }^{1 *}$ and Michael T Heneka ${ }^{1,2}$
}

\begin{abstract}
Alzheimer's disease pathology is closely connected to the processing of the amyloid precursor protein (APP) resulting in the formation of a variety of amyloid-beta $(A \beta)$ peptides. They are found as insoluble aggregates in senile plaques, the histopathological hallmark of the disease. These peptides are also found in soluble, mostly monomeric and dimeric, forms in the interstitial and cerebrospinal fluid. Due to the combination of several enzymatic activities during APP processing, A $\beta$ peptides exist in multiple isoforms possessing different $\mathrm{N}$-termini and $\mathrm{C}$-termini. These peptides include, to a certain extent, part of the juxtamembrane and transmembrane domain of APP. Besides differences in size, post-translational modifications of A $\beta$ - including oxidation, phosphorylation, nitration, racemization, isomerization, pyroglutamylation, and glycosylation - generate a plethora of peptides with different physiological and pathological properties that may modulate disease progression.
\end{abstract}

\section{Introduction}

Since its identification from senile plaques, amyloid-beta $(\mathrm{A} \beta)$ peptide has been considered to play a central role in the pathology of Alzheimer's disease (AD) [1]. A $\beta$ is thought to accumulate in AD cases because of an imbalance in the production and clearance of this peptide resulting in the formation of the characteristic amyloid plaques in specific brain regions. The large majority of $\mathrm{AD}$ cases are of sporadic nature, showing inefficient removal of $A \beta$ [2], whereas a minority of cases is caused by genetic mutations (familial AD) with an onset typically below age 65 years. Most of these cases are caused by autosomal dominant mutations in genes related to the processing of amyloid precursor protein (APP) leading to increased production of $A \beta$.

To generate $A \beta$ from APP, the precursor has to be cleaved by a set of two proteases (Figure 1). The first cleavage occurs at a luminal, juxtamembrane position, resulting in the formation of a membrane-bound C-terminal stub that, in a subsequent step, is cleaved by an unconventional protease complex, called $\gamma$-secretase, within the transmembrane domain, thereby liberating $A \beta$. Both cleavages have been shown to be imprecise. $\beta$-site amyloid precursor protein cleaving enzyme 1 (BACE1), the enzyme that conducts the initial processing, step-cleaves APP at a minimum of two positions, whereas

\footnotetext{
* Correspondence: markus.kummer@ukb.uni-bonn.de

${ }^{1}$ Department of Neurology, University Hospital Bonn, Sigmund-Freud-Strasse 25, 53127 Bonn, Germany

Full list of author information is available at the end of the article
}

$\gamma$-secretase generates a variety of different $A \beta s$ spanning 34 to 50 amino acids in length.

Most AD cases are sporadic, however, without changes in the production of the $A \beta$ peptide. The propensity to form aggregates and toxic species may therefore be driven by factors other than changes in the production of certain A $\beta$ peptides. Several post-translational modifications (PTMs) have been discovered that on the whole increase the aggregation rate of $A \beta$ (Figure 2). Some of these modifications, such as oxidation and nitration, are obviously induced by the inflammatory milieu that is a component of $\mathrm{AD}$ [3].

PTMs can function as a molecular switch to evoke cellular responses, but one should consider that they may also be a result of protein aging that is random and without any physiological impact.

\section{Truncated amyloid-beta species}

Amyloid-beta species generated by $a$-secretase, $\beta$-secretase, and $\gamma$-secretase

Three enzymatic activities are involved in APP processing, and were named $\alpha$-secretase, $\beta$-secretase, and $\gamma$-secretase at a time when their molecular identities were unknown. APP exists in several isoforms ranging from 695 to 770 amino acids in length, including the domain from which the A $\beta$ peptide derives. In APP695 (the most abundant isoform in the brain) this domain ranges from amino acids 597 to 638 . In an initial step, APP is cleaved at a juxtamembrane position at the luminal side of the membrane. This cleavage is mediated 


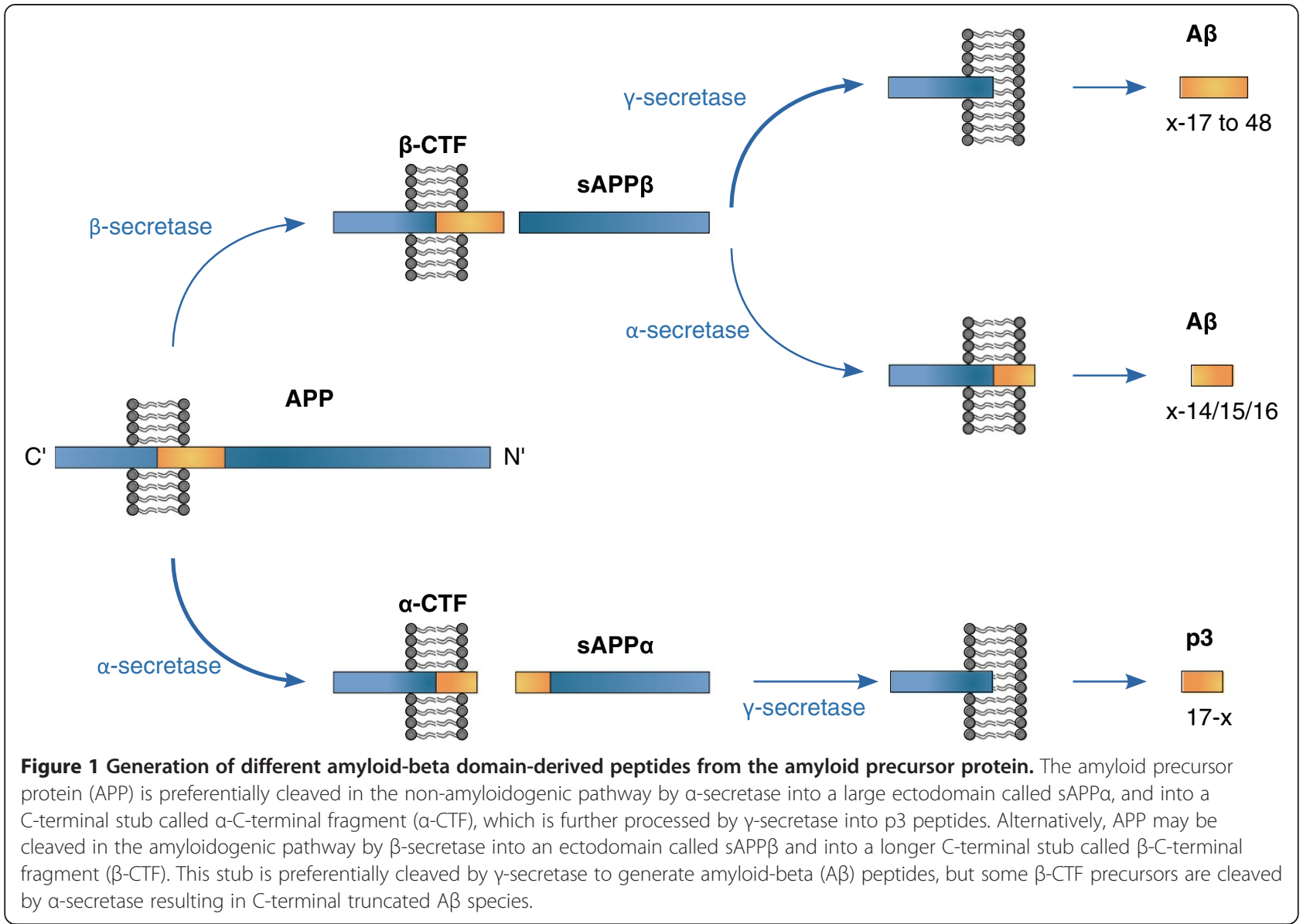

at different positions by either $\alpha$-secretase or $\beta$-secretase in different compartments of the cell [4]. The majority of APP molecules in non-neuronal cells are initially cleaved by $\alpha$-secretase between positions 16 and 17 of the $A \beta$ domain. This is the so-called non-amyloidogenic pathway since the cleavage occurs within the $A \beta$ domain, thereby preventing the production of $\mathrm{A} \beta$. This event generates a stub called $\alpha$-C-terminal fragment as well as a large ectodomain called SAPP $\alpha$. Several members of the ADAM family of proteases are able to mediate this cleavage, but in neurons this function is likely to be exerted by the constitutively active ADAM10 protease [5].

In the amyloidogenic pathway, leading to the production of $A \beta$ peptides, $\beta$-secretase mediates the initial ratelimiting step. The membrane-bound aspartyl-protease BACE1 has been identified as the responsible enzyme. APP is cleaved by this enzyme before position 1 of the $A \beta$ domain [6], resulting in the release of a large ectodomain and the formation of a stub called $\beta$-C-terminal fragment. In addition, BACE1 can also cleave APP within the $A \beta$ domain between positions 10 and $11\left(\beta^{\prime}\right.$ site) [7]. Subsequently, both N-terminally cleaved precursors are further processed by $\gamma$-secretase, a complex that consists of at least the proteins APH-1, PEN-2, nicastrin and presenilin 1 or presenilin 2 [8]. The transmembrane proteins presenilin 1 and presenilin 2 possess two critical aspartyl residues that are part of the catalytic domain of this $\gamma$-secretase subunit. The cleavage occurs within the transmembrane domain of APP, generating C-terminally truncated peptides ending with amino acids 37 to 43 , due to an imprecise cleavage of these enzymes. The resulting peptides are liberated into extracellular fluids such as cerebrospinal fluid (CSF), plasma or interstitial fluid. This phenomenon is not fully understood, but endoproteolysis is thought to occur stepwise, cleaving the C-terminal stubs several times within their transmembrane domain. These cleavages are approximately three amino acids apart $[9,10]$ : one at amino acid 48 or 49 , followed by another one at position 45 or 46 , and ending with a final cleavage most often at position 38 , 40 or 42 . At least in the CSF of nondemented controls, about one-half of the $A \beta$ ends at amino acid 40, 16\% ends at amino acid 38, and 10\% ends at amino acid 42 [11]. A $\beta$ species ending with the alanine at position 42 have a stronger tendency to aggregate as compared with A $\beta 1-40$. These species are thought to be the driving factor for the formation of amyloid plaques and the neurotoxic effects [12]. During this last step, other minor 


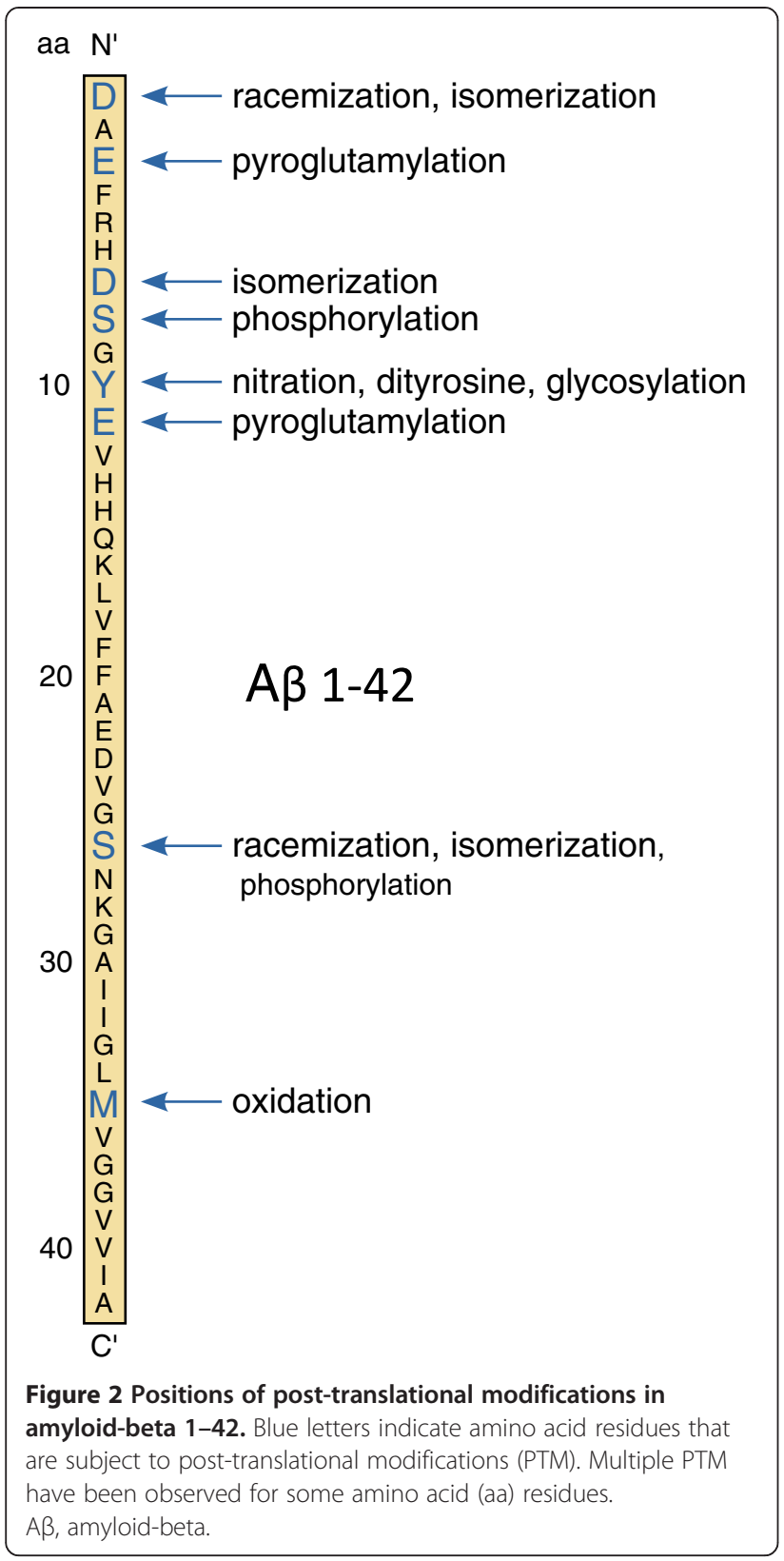

cleavage sites have been observed at positions $34,37,39$, and 43 [9]. There are even shorter $A \beta$ isoforms $(A \beta 1-$ $17 / 18 / 19 / 20)$ that depend on $\gamma$-secretase $[13,14]$ but the precise mechanism of their generation is unknown.

Both processing pathways lead to a large variety of peptides that start either at position 1 or position 11 caused by cleavage by BACE1 or at position 17 mediated by $\alpha$-secretase. The latter peptides are called p3 [15] but are not found in senile plaques, and neither do they yet appear to have any pathological or physiological role. Most of these $\mathrm{N}$-terminal starting points are found in combination with the heterogeneity caused by the cleavage of $\gamma$-secretase.
To make things even more complicated, the amyloidogenic pathway and the nonamyloidogenic pathway seem not to be mutually exclusive. There are shorter isoforms of $A \beta(A \beta 1-14 / 15 / 16)$ present in the CSF that do not depend on $\gamma$-secretase cleavage but are sensitive to inhibitors of $\alpha$-secretase. Interestingly, $A \beta 1-14 / 15 / 16$ increase after $\gamma$-secretase treatment in CSF $[16,17]$. This leads to the conclusion that C-terminal BACE1-cleaved stubs (C99) are not exclusive substrates for $\gamma$-secretase, and that C99 can reach compartments with $\alpha$-secretase activity resulting in the liberation of $\mathrm{A} \beta 1-14 / 15 / 16$ along alternative pathways $[13,14,18]$.

\section{$\mathrm{N}$-terminal amyloid-beta truncations independent of $\mathrm{a}$ - secretase or $\beta$-secretase}

There are several $\mathrm{N}$-terminal truncations observed in AD that cannot be explained by the action of the abovedescribed enzymes [19]. In general, N-terminal truncations make up the majority of $A \beta$ species in $A D[20,21]$ but not in the transgenic mice mouse model, which might explain the differences in the molecular mechanisms of amyloid deposition [20,22]. In addition, the shortening of the $\mathrm{N}$-terminus increases the propensity of $A \beta$ to form aggregates in vitro [23]. Since $A \beta$ is degraded by several secretory proteases, such as insulin-degrading enzyme and neprilysin among others [24], it is possible that truncations arise from these enzymes.

The 2-x $A \beta$ species has been found to be increased in the brains of $A D$ patients $[25,26]$ and decreased in the CSF of AD patients [27]. There was a suggestion that this species might derive from the combined action of BACE1 followed by aminopeptidase A [25]. Recently, the metalloprotease meprin-beta was reported to initially shed APP in a BACE1-independent fashion, releasing different $A \beta$ species with several cleavage sites. These sites are reported to be identical with or proximal to the known $\beta$-secretase cleavage site [28], and overexpression of meprin-beta generates A $\beta 2-40[11,25]$. However, further studies and appropriate mouse models are necessary to investigate the contribution of meprin-beta in AD.

The 3-x $A \beta$ species has been detected in a mouse model of $A D[20,29,30]$ and in senile plaques from brains of late $\mathrm{AD}$ cases [31]. It has been suggested that this species is generated by $\mathrm{Cu}^{2+}$-mediated amide hydrolysis or the peptide bond between amino acids 2 and 3 of $A \beta$ [32].

One of the first $A \beta$ peptides reported was the $\mathrm{N}$ terminal truncated 4-x species [33]. In comparison with other species, A $\beta 4-42$ was found to be relatively abundant in $\mathrm{AD}$ and vascular dementia [34]. In vivo, mice overexpressing A $\beta 4-42$ suffer from a massive CA1 pyramidal neuronal loss, accompanied by memory dysfunction [35]. There is so far no candidate enzyme that mediates this cleavage. 
The 5-x A $\beta$ species was initially described in cells expressing an APP lacking the C-terminal 31 amino acids, but has also been discovered in AD patients using a 5-x A $\beta$ neo-epitope antibody [36,37] and in nondemented controls by mass spectometry [21]. Interestingly, using APP-overexpressing cell lines, inhibition of BACE1 resulted in the appearance of $A \beta 5-40$ [38,39]. This species has also been detected in the 5XFAD mouse model of $\mathrm{AD}[29]$ and in the CSF of dogs treated with BACE1 inhibitor [39].

The largest amino truncations, aside from that at position 11 mediated by BACE1, are so far the cleavages that occur before amino acids 7, 8 and 9 observed in the brains of $\mathrm{AD}$ patients [21,22]. A candidate enzyme for the formation of the $8-x \quad A \beta$ species might be angiotensin-converting enzyme [40], but so far there are no in vivo data supporting this pathway.

\section{Amyloid-beta species modified by post- translational modification Oxidation}

The most prominent site of oxidative changes within $A \beta$ is the methionine at position 35 (Met35). Increased oxidative stress has been described in the brains of mild cognitive impaired and AD patients. Part of this oxidative stress is mediated by the $A \beta$ peptide itself, but other mechanisms, such as inflammatory inducers and others, may also be relevant.

Oxidation of Met35 to methionine sulfoxide in $\mathrm{AD}$ was first observed years ago [41]. The reaction proceeds through a radical intermediate that can be prevented by the use of radical scavengers [42]. Several studies demonstrated that oxidation of Met35 impedes the formation of $A \beta$ protofibrils and fibrils from monomers $[43,44]$. A role for Met35-oxidized $A \beta$ in the formation of ion-channel-like structures in lipid membranes has also been reported [45].

\section{Phosphorylation}

In theory, $A \beta$ possesses three potential phosphorylation sites at serine residues 8 and 26 and at tyrosine residue 10. There are numerous examples of phosphorylated extracellular/luminal protein suggesting the existence of extracellular kinases that facilitate this PTM. Phosphorylation of the serine at position 26 has been described in NT2 neurons and AD brains [46]. In vitro, this PTM is generated by the action of the cdc2 kinase. In turn, using a cdc2 kinase inhibitor, the neurotoxic effect of $A \beta$ on NT-2 neurons can be reduced [46].

Phosphorylation of $A \beta$ at serine 8 has been studied in more detail. Using phospho-serine-8-specific $A \beta$ antibodies revealed the presence of phosphorylated $A \beta$ in AD mouse models and AD. Under pathological conditions this species was found to be localized to amyloid plaques [47], but could also be found intracellularly [48]. Biophysically, this PTM increases the formation of oligomeric $A \beta$ aggregates that represent nuclei for fibrillization. This species shows increased toxicity in drosophila models as compared with nonphosphorylated $A \beta$ [47]. In addition, serine 8-phosphorylated $A \beta$ is resistant to degradation by insulin degrading enzyme [49].

\section{Nitric-oxide-caused modifications}

Nitric oxide (NO) induces several PTMs, including the formation of S-nitrothiols at cysteine residues and nitration and dityrosine formation at tyrosine residues [50]. Increased presence of these NO-caused PTMs has been observed in $\mathrm{AD}[51,52]$. The source of $\mathrm{NO}$ during $\mathrm{AD}$ is most probably the enzyme NOS2, which is upregulated in $\mathrm{AD}[53,54]$. As a molecular target, tyrosine 10 of $\mathrm{A} \beta$ has been shown to increase the propensity of $A \beta$ to aggregate and has been identified in the core of the amyloid plaques [55]. The reaction of $A \beta$ with peroxynitrite, an intermediate $\mathrm{NO}$ product, in vitro has been shown to generate both nitrated $A \beta$ and dityrosine-coupled $A \beta$. The latter modification could also be detected in the core of amyloid plaques [55] and may stabilize $A \beta$ dimers [56]. Nitrated $A \beta$ was able to initiate plaque formation in APP/PS1 mice, suggesting a central role during the early phase of AD [55]. Hippocampal long-term potentiation was suppressed more by nitrated $A \beta$ compared with non-nitrated $A \beta$. This demonstrates that this PTM is involved in both the functional and structural changes in $A D$. In addition, formation of this $A \beta$ species is favored by oxidative stress [56,57].

\section{Glycosylations}

Mass spectrometry analysis of controls and AD patients revealed the presence of $\mathrm{O}$-glycosylated $\mathrm{A} \beta$ species in CSF [58]. The glycoforms included monosialylated, disialylated, and trisialylated modifications, as well as lactone modifications. The exact molecular nature of the glycosylation has not been determined and could therefore be GlcNAc, GalNAc, or ManNAc in either $\alpha$-linkage or $\beta$ linkage to the conjugated amino acid. Glycosylation occurred on $A \beta 1-15 / 16 / 17 / 18 / 19 / 20, A \beta 3-15, A \beta 4-15$, $A \beta 4-17$, and $A \beta 5-17$ peptides, with $A \beta 1-15$ and $A \beta 1-$ 17 peptides being the most abundant of all $A \beta 1-X$ glycopeptides. The absolute concentration for glycosylated A $\beta 1-15$ was calculated to be 10 to $30 \mathrm{pg} / \mathrm{ml} \mathrm{CSF}$, whereas that for unglycosylated $A \beta 1-15$ ranged from 100 to $200 \mathrm{pg} / \mathrm{ml}$. For $A \beta 1-15$ and $A \beta 1-17$ the glycosylations were selectively attached to tyrosine 10 of the $A \beta$ sequence. The lack of glycosylated $A \beta 1-40 / 42$ peptides in CSF led to the conclusion that tyrosine $10 \mathrm{O}$ glycosylation in APP modifies the $\gamma$-secretase cleavage, because of the proximity of this glycosylation to the transmembrane domain [58]. 


\section{Pyroglutamylation}

The initial attempts to identity the $\mathrm{N}$-terminus of $\mathrm{A} \beta$ revealed a minor species beginning with glutamic acid at position 3 [59]. Development of specific antibodies to pyroglutamate $A \beta$ demonstrated its weak solubility and presence in amyloid plaques [60]. As an initial step, formation of pyroglutamate-modified $A \beta$ at position 3 $(3 \mathrm{pE}-\mathrm{A} \beta)$ requires the removal of the first two amino acids from $A \beta$. Aminopeptidase $A$ has been suggested as an enzyme facilitating this processing [61], but this has yet to be proven. In addition, spontaneous amide hydrolysis by $\mathrm{Cu}^{2+}$ has been reported [32]. Further, another pyroglutamate modification at aspartate 11 was discovered $(11 \mathrm{pE}-\mathrm{A} \beta)[41,62]$. This species may arise from the alternative BACE1 cleavage side in APP [63,64]. In a subsequent step, the terminal glutamate is converted to a pyroglutamate in a dehydration reaction. This reaction can be catalyzed by the enzyme glutaminyl cyclase [65], which is increased in AD [66]. Reduction of glutaminyl cyclase results in reduced formation of pyroglutamate $\mathrm{A} \beta$ in vitro [67] and in vivo [66,68]. Further, reduced glutaminyl cyclase expression in AD mouse models is accompanied by reductions in A $\beta 40 / 42$ levels, reduced plaque burden, inflammatory reaction, and improved memory and spatial learning [66,68].

In vitro, $3 \mathrm{pE}-\mathrm{A} \beta 42$ has a similar toxicological profile on neuronal cells to that of A $\beta 1-42$ [69], which was confirmed by intracerebroventricular injections of either $3 p E-A \beta 42$ or $A \beta 1-42$ [70]. Like many changes in the $\mathrm{N}$ terminus of $A \beta, 3 p E-A \beta$ and $11 \mathrm{pE}-\mathrm{A} \beta$ show increased propensity to aggregate and to form $\beta$-sheets in vitro. This may be caused by higher hydrophobicity since two charges are lost during conversion [71]. pE-A $\beta$ has been detected in a variety of $\mathrm{AD}$ mouse models, yet the time of first appearance during pathology varies strongly between different mouse models - ranging from 2 months in the APP/PS1KI model [72], to 16 months in the Tg2576 model [73], to 15 months in the APP23 model [20]. Interestingly, there has been extensive neurotoxicity described in mouse models that generate pyroglutamatemodified A $\beta[74,75]$.

\section{Isomerization}

Peptides are susceptible to spontaneous, non-enzymatic isomerization particularly at asparagine and aspartate residues, resulting in the formation of isoaspartate. These aspartyl-bond isomerizations affect the secondary structure of the peptide and may therefore be critical for the development of pathological processes such as aggregation and deposition [76]. In parenchymal plaque core preparations, the predominant species of $A \beta$ at the aspartyl residues 1 and 7 is the L-isoaspartyl form [77]. Interestingly, the amount of isoaspartyl residues in $A \beta$ preparations from vascular depositions is lower compared with preparations from senile plaques [77,78], suggesting that $A \beta$ from plaques are older since this PTM increases over the lifetime. Isomerization of aspartate 23 has not so far been detected by biochemical means in $\mathrm{AD}$ brains.

In vitro, substitutions of positions 1,7 and 23 of $A \beta$ by isoaspartate increased the tendency of these peptides to form $\beta$-pleated sheets [78], to form aggregates [79,80] and to contribute to the enhanced insolubility and resistance to enzymatic degradation [81]. The presence of isoaspartate- $7 \mathrm{~A} \beta$ detected by specific antibodies was suggested to be an indicator of plaque age since this was found mostly in the core of amyloid plaques and correlated with dementia severity [82].

\section{Racemization}

Racemization is the process of conversion of enantiomers so that both enantiomers are present. In the case of amino acids this is the conversion from the L-form to the D-form, especially at seryl and aspartyl residues. Presence of D-enantiomers of aspartyl and seryl residues in $A \beta$ have long been described [83-85]. As for isomerized $A \beta$, the presence of racemized aspartyl residues in $A \beta$ was found to be higher in amyloid plaques compared with vascular $A \beta$ [77]. In vitro, racemization of $A \beta$ can be induced by radicals [86]. In a recent study, the enrichment of $\mathrm{D}$ - $\mathrm{Asp}^{1}$ as well as of its isomer $\mathrm{D}$-isoAsp ${ }^{1}$ could be demonstrated in the tissue of $\mathrm{AD}$ patients by mass spectometry [87]. D-Ser ${ }^{26}-\mathrm{A} \beta 1-40$ possesses a stronger tendency to form fibrils [84].

\section{Use of amyloid-beta species as diagnostic marker and as a target for treatment}

Because of its disease-dependent regulation in the CSF, $\mathrm{A} \beta$ has been used as a biomarker for AD. In particular, the concentration of A $\beta 1-42$ in the CSF undergoes a characteristic drop during disease progression, which is interpreted as the consequence of the ongoing parenchymal $A \beta$ deposition in senile plaques. In addition, the CSF levels of $A \beta 1-40$ remain constant so that the ratio of $A \beta 1-42$ / $\mathrm{A} \beta 1-40$ is a valuable predictor. Since the $\mathrm{C}$-terminal truncated $A \beta 1-14 / 15$ species are elevated after inhibition of $\gamma$ secretase, their use as a readout for trials aiming at the modulation of $\gamma$-secretase has been suggested [88]. The sensitivity can be increased by combining the markers $A \beta 1-42, A \beta 1-38$ and pTau, resulting in a $94 \%$ discrimination between nondemented patients and $\mathrm{AD}$ patients [89]. Beyond the diagnosis of $\mathrm{AD}$, the concentration of A $31-38$ is specifically lowered in the CSF of patients affected by fronto-temperal dementia [90].

The search for human auto-antibodies in plasma and CSF revealed that most antibodies recognized either oligomeric or post-translationally modified $A \beta$ [91], suggesting that this species might be a relevant target for 
passive or active immunotherapy. Since it is unknown whether unmodified $A \beta$ has a physiological role, there is a certain risk that preventive immunotherapy may cause undesirable effects. In addition, decreased levels of $A \beta$ autoantibodies might even contribute to disease progression as has been shown for pyroglutamate-modified $A \beta$ [92]. The immunotherapy directed at pathological $A \beta$ species is therefore a road that should be followed.

Several PTMs of $A \beta$ increase the tendency of $A \beta$ to aggregate $[46,57,91]$ and are found in the core of amyloid plaques $[55,93]$, suggesting that plaque formation depends on them. The use of inhibitors that interfere with their formation therefore has to be evaluated. In particular, inhibitors for glutaminyl cyclase [66], the relevant kinases for the phosphorylation of $\mathrm{A} \beta$ and NO-producing enzymes, especially NOS2 [55], should be tested as a therapeutic option.

\section{Conclusion}

From the plethora of $A \beta$ species, some are generated very early during APP processing, some are modified immediately afterwards, or others are found or generated in certain cellular or extracellular compartments, and some are actually markers for the slow to non-existent turnover of these peptides in amyloid plaques. Certain regions of $A \beta$ obviously contribute differentially to its properties, like $\mathrm{N}$-terminal truncations, and certain amino acids are hotspots for PTMs. There is a possibility that some of these species might serve as excellent diagnostic markers or therapeutic targets in the future.

\section{Abbreviations \\ AD: Alzheimer's disease; APP: Amyloid precursor protein; A $\mathrm{B}$ : Amyloid-beta; BACE1: $\beta$-site amyloid precursor protein cleaving enzyme 1; CSF: Cerebrospinal fluid; Met35: Methionine at position 35; NO: Nitric oxide; PTM: Post-translational modification.}

\section{Competing interests}

The authors declare that they applied for a patent for the use of nitrated $A B$.

\section{Authors' contributions}

MPK and MTH wrote the manuscript. Both authors read and approved the final manuscript.

\section{Acknowledgements}

The authors would like to thank Catherine Widmann, Dr Sascha Weggen and Dr Claus Pietrzik for discussion. This study was supported by the Deutsche Forschungsgemeinschaft (KFO177, TP4) to MTH and by grants of the INMiND project of the European Union to MTH. MTH is member of the DFG Cluster of Excellence ImmunoSensation.

\section{Author details}

'Department of Neurology, University Hospital Bonn, Sigmund-Freud-Strasse 25, 53127 Bonn, Germany. ${ }^{2}$ German Center for Neurodegenerative Diseases (DZNE), Holbeinstrasse 15, 53117 Bonn, Germany.

Published: 26 May 2014

\section{References}

1. Querfurth HW, LaFerla FM: Alzheimer's disease. N Engl J Med 2010, 362:329-344.
2. Mawuenyega KG, Sigurdson W, Ovod V, Munsell L, Kasten T, Morris JC, Yarasheski KE, Bateman RJ: Decreased clearance of CNS $\beta$-amyloid in Alzheimer's disease. Science 2010, 330:1774-1774.

3. Heneka MT, O'Banion MK, Terwel D, Kummer MP: Neuroinflammatory processes in Alzheimer's disease. J Neural Transm Vienna Austria 1996 2010, 117:919-947.

4. Thinakaran $\mathrm{G}, \mathrm{KoO}$ EH: Amyloid precursor protein trafficking, processing, and function. J Biol Chem 2008, 283:29615-29619.

5. Kuhn P-H, Wang H, Dislich B, Colombo A, Zeitschel U, Ellwart JW, Kremmer E, Rossner S, Lichtenthaler SF: ADAM10 is the physiologically relevant, constitutive alpha-secretase of the amyloid precursor protein in primary neurons. EMBO J 2010, 29:3020-3032.

6. Vassar R, Bennett BD, Babu-Khan S, Kahn S, Mendiaz EA, Denis P, Teplow DB, Ross S, Amarante P, Loeloff R, Luo Y, Fisher S, Fuller J, Edenson S, Lile J, Jarosinski MA, Biere AL, Curran E, Burgess T, Louis JC, Collins F, Treanor J, Rogers G, Citron M: Beta-secretase cleavage of Alzheimer's amyloid precursor protein by the transmembrane aspartic protease BACE. Science 1999, 286:735-741.

7. Seubert P, Vigo-Pelfrey C, Esch F, Lee M, Dovey H, Davis D, Sinha S, Schlossmacher M, Whaley J, Swindlehurst C: Isolation and quantification of soluble Alzheimer's beta-peptide from biological fluids. Nature 1992 359:325-327.

8. Edbauer D, Winkler E, Regula JT, Pesold B, Steiner H, Haass C: Reconstitution of gamma-secretase activity. Nat Cell Biol 2003, 5:486-488.

9. Takami M, Nagashima Y, Sano Y, Ishihara S, Morishima-Kawashima M, Funamoto $S$, Ihara Y: $\gamma$-Secretase: successive tripeptide and tetrapeptide release from the transmembrane domain of beta-carboxyl terminal fragment. J Neurosci Off J Soc Neurosci 2009, 29:13042-13052.

10. Qi-Takahara Y, Morishima-Kawashima M, Tanimura Y, Dolios G, Hirotani N, Horikoshi Y, Kametani F, Maeda M, Saido TC, Wang R, Ihara Y: Longer forms of amyloid beta protein: implications for the mechanism of intramembrane cleavage by gamma-secretase. J Neurosci Off J Soc Neurosci 2005, 25:436-445.

11. Bibl M, Gallus M, Welge V, Lehmann S, Sparbier K, Esselmann H, Wiltfang J: Characterization of cerebrospinal fluid aminoterminally truncated and oxidized amyloid- $\beta$ peptides. Proteomics Clin Appl 2012, 6:163-169.

12. Haass C, Selkoe DJ: Soluble protein oligomers in neurodegeneration: lessons from the Alzheimer's amyloid beta-peptide. Nat Rev Mol Cell Biol 2007, 8:101-112.

13. Beher D, Wrigley JDJ, Owens AP, Shearman MS: Generation of C-terminally truncated amyloid- $\beta$ peptides is dependent on $\gamma$-secretase activity. J Neurochem 2002, 82:563-575.

14. Portelius E, Price E, Brinkmalm G, Stiteler M, Olsson M, Persson R, Westman-Brinkmalm A, Zetterberg H, Simon AJ, Blennow K: A novel pathway for amyloid precursor protein processing. Neurobiol Aging 2011, 32:1090-1098.

15. Haass C, Hung AY, Schlossmacher MG, Teplow DB, Selkoe DJ: $\beta$-Amyloid peptide and a 3-kDa fragment are derived by distinct cellular mechanisms. J Biol Chem 1993, 268:3021-3024.

16. Portelius E, Van Broeck B, Andreasson U, Gustavsson MK, Mercken M, Zetterberg $H$, Borghys $H$, Blennow $K$ : Acute effect on the $A \beta$ isoform pattern in CSF in response to $\gamma$-secretase modulator and inhibitor treatment in dogs. J Alzheimers Dis 2010, 21:1005-1012.

17. Portelius E, Dean RA, Gustavsson MK, Andreasson U, Zetterberg H, Siemers E, Blennow $K$ : A novel $A \beta$ isoform pattern in CSF reflects gamma-secretase inhibition in Alzheimer disease. Alzheimers Res Ther 2010, 2:7.

18. Jäger S, Leuchtenberger S, Martin A, Czirr E, Wesselowski J, Dieckmann M, Waldron E, Korth C, Koo EH, Heneka M, Weggen S, Pietrzik CU: Alphasecretase mediated conversion of the amyloid precursor protein derived membrane stub C99 to C83 limits A $\beta$ generation. J Neurochem 2009, 111:1369-1382.

19. Ancolio K, Dumanchin C, Barelli H, Warter JM, Brice A, Campion D, Frébourg $\mathrm{T}$, Checler F: Unusual phenotypic alteration of beta amyloid precursor protein (BAPP) maturation by a new Val-715 $\rightarrow$ Met $\beta$ APP-770 mutation responsible for probable early-onset Alzheimer's disease. Proc Natl Acad Sci USA 1999, 96:4119-4124.

20. Schieb H, Kratzin H, Jahn O, Möbius W, Rabe S, Staufenbiel M, Wiltfang J, Klafki HW: Beta-amyloid peptide variants in brains and cerebrospinal fluid from amyloid precursor protein (APP) transgenic mice: comparison with human Alzheimer amyloid. J Biol Chem 2011, 286:33747-33758 
21. Sergeant N, Bombois S, Ghestem A, Drobecq H, Kostanjevecki V, Missiaen C, Wattez A, David J-P, Vanmechelen E, Sergheraert C, Delacourte A: Truncated beta-amyloid peptide species in pre-clinical Alzheimer's disease as new targets for the vaccination approach. J Neurochem 2003, 85:1581-1591.

22. Kalback W, Watson MD, Kokjohn TA, Kuo Y-M, Weiss N, Luehrs DC, Lopez J, Brune D, Sisodia SS, Staufenbiel M, Emmerling M, Roher AE: APP transgenic mice $\operatorname{Tg} 2576$ accumulate $A \beta$ peptides that are distinct from the chemically modified and insoluble peptides deposited in Alzheimer's disease senile plaques. Biochemistry (Mosc) 2002, 41:922-928.

23. Pike CJ, Overman MJ, Cotman CW: Amino-terminal deletions enhance aggregation of $\beta$-amyloid peptides in vitro. J Biol Chem 1995, 270:23895-23898.

24. Wang DS, Dickson DW, Malter JS: $\beta$-Amyloid degradation and Alzheimer's disease. J Biomed Biotechnol 2006, 2006:58406.

25. Wiltfang J, Esselmann $H$, Cupers $P$, Neumann M, Kretzschmar H, Beyermann M, Schleuder D, Jahn H, Rüther E, Kornhuber J, Annaert W, De Strooper B, Saftig P: Elevation of beta-amyloid peptide $2-42$ in sporadic and familial Alzheimer's disease and its generation in PS1 knockout cells. J Bio/ Chem 2001, 276:42645-42657.

26. Arai T, Akiyama $\mathrm{H}$, Ikeda $\mathrm{K}$, Kondo $\mathrm{H}$, Mori $\mathrm{H}$ : Immunohistochemical localization of amyloid beta-protein with amino-terminal aspartate in the cerebral cortex of patients with Alzheimer's disease. Brain Res 1999, 823:202-206.

27. Bibl M, Gallus M, Welge V, Esselmann $H$, Wolf $S$, Rüther E, Wiltfang J: Cerebrospinal fluid amyloid- $\beta$ 2-42 is decreased in Alzheimer's, but not in frontotemporal dementia. J Neural Transm Vienna Austria 1996 2012, 119:805-813.

28. Bien J, Jefferson T, Causević M, Jumpertz T, Munter L, Multhaup G, Weggen S, Becker-Pauly C, Pietrzik CU: The metalloprotease meprin $\beta$ generates amino terminal-truncated amyloid $\beta$ peptide species. J Biol Chem 2012, 287:33304-33313.

29. Wittnam JL, Portelius E, Zetterberg H, Gustavsson MK, Schilling S, Koch B, Demuth $\mathrm{H}-\mathrm{U}$, Blennow K, Wirths O, Bayer TA: Pyroglutamate amyloid $\beta$ $(A \beta)$ aggravates behavioral deficits in transgenic amyloid mouse model for Alzheimer disease. J Biol Chem 2012, 287:8154-8162.

30. Casas C, Sergeant N, Itier J-M, Blanchard V, Wirths O, van der Kolk N, Vingtdeux V, van de Steeg E, Ret G, Canton T, Drobecq H, Clark A, Bonici B, Delacourte A, Benavides J, Schmitz C, Tremp G, Bayer TA, Benoit P, Pradier L: Massive CA1/2 neuronal loss with intraneuronal and $\mathrm{N}$-terminal truncated $A \beta 42$ accumulation in a novel Alzheimer transgenic model. Am J Pathol 2004, 165:1289-1300.

31. Güntert A, Döbeli H, Bohrmann B: High sensitivity analysis of amyloid-beta peptide composition in amyloid deposits from human and PS2APP mouse brain. Neuroscience 2006, 143:461-475.

32. Drew SC, Masters CL, Barnham KJ: Alanine-2 carbonyl is an oxygen ligand in $\mathrm{Cu}^{2+}$ coordination of Alzheimer's disease amyloid-beta peptide - relevance to N-terminally truncated forms. J Am Chem Soc 2009, 131:8760-8761.

33. Masters $C L$, Simms $G$, Weinman NA, Multhaup G, McDonald BL, Beyreuther K: Amyloid plaque core protein in Alzheimer disease and Down syndrome. Proc Natl Acad Sci USA 1985, 82:4245-4249.

34. Lewis H, Beher D, Cookson N, Oakley A, Piggott M, Morris CM, Jaros E, Perry R, Ince P, Kenny RA, Ballard CG, Shearman MS, Kalaria RN: Quantification of Alzheimer pathology in ageing and dementia: age-related accumulation of amyloid-beta(42) peptide in vascular dementia. Neuropathol Appl Neurobiol 2006, 32:103-118.

35. Bouter $Y$, Dietrich K, Wittnam JL, Rezaei-Ghaleh N, Pillot T, Papot-Couturier S, Lefebvre T, Sprenger F, Wirths O, Zweckstetter M, Bayer TA: N-truncated amyloid $\beta$ (A $\beta$ ) 4-42 forms stable aggregates and induces acute and long-lasting behavioral deficits. Acta Neuropathol (Berl) 2013, 126:189-205.

36. Takeda K, Araki W, Akiyama H, Tabira T: Amino-truncated amyloid betapeptide (AB5-40/42) produced from caspase-cleaved amyloid precursor protein is deposited in Alzheimer's disease brain. FASEB J Off Publ Fed Am Soc Exp Biol 2004, 18:1755-1757.

37. Murayama KS, Kametani F, Tabira T, Araki W: A novel monoclonal antibody specific for the amino-truncated beta-amyloid $A \beta 5-40 / 42$ produced from caspase-cleaved amyloid precursor protein. J Neurosci Methods 2007, 161:244-249.

38. Portelius E, Olsson M, Brinkmalm G, Rüetschi U, Mattsson N, Andreasson U, Gobom J, Brinkmalm A, Hölttä M, Blennow K, Zetterberg H: Mass spectrometric characterization of amyloid- $\beta$ species in the 7PA2 cell model of Alzheimer's disease. J Alzheimers Dis 2013, 33:85-93.

39. Mattsson N, Rajendran L, Zetterberg H, Gustavsson M, Andreasson U, Olsson M, Brinkmalm G, Lundkvist J, Jacobson LH, Perrot L, Neumann U, Borghys $H_{\text {, }}$ Mercken M, Dhuyvetter D, Jeppsson F, Blennow K, Portelius E: BACE1 inhibition induces a specific cerebrospinal fluid $\beta$-amyloid pattern that identifies drug effects in the central nervous system. PloS One 2012, 7: e31084.

40. $\mathrm{Hu}$ J, Igarashi A, Kamata M, Nakagawa H: Angiotensin-converting enzyme degrades Alzheimer amyloid beta-peptide (AB); retards $A \beta$ aggregation, deposition, fibril formation; and inhibits cytotoxicity. J Biol Chem 2001, 276:47863-47868.

41. Näslund J, Schierhorn A, Hellman U, Lannfelt $L$, Roses AD, Tjernberg LO, Silberring J, Gandy SE, Winblad B, Greengard P: Relative abundance of Alzheimer $A \beta$ amyloid peptide variants in Alzheimer disease and normal aging. Proc Natl Acad Sci USA 1994, 91:8378-8382.

42. Hensley K, Aksenova M, Carney JM, Harris M, Butterfield DA: Amyloid beta-peptide spin trapping. I: peptide enzyme toxicity is related to free radical spin trap reactivity. Neuroreport 1995, 6:489-492.

43. Palmblad M, Westlind-Danielsson A, Bergquist J: Oxidation of methionine 35 attenuates formation of amyloid beta-peptide 1-40 oligomers. J Biol Chem 2002, 277:19506-19510.

44. Hou L, Kang I, Marchant RE, Zagorski MG: Methionine 35 oxidation reduces fibril assembly of the amyloid $A \beta-(1-42)$ peptide of Alzheimer's disease. J Biol Chem 2002, 277:40173-40176.

45. Barnham KJ, Ciccotosto GD, Tickler AK, Ali FE, Smith DG, Williamson NA, Lam Y-H, Carrington D, Tew D, Kocak G, Volitakis I, Separovic F, Barrow CJ, Wade JD, Masters CL, Cherny RA, Curtain CC, Bush Al, Cappai R: Neurotoxic, redox-competent Alzheimer's beta-amyloid is released from lipid membrane by methionine oxidation. J Biol Chem 2003, 278:42959-42965.

46. Milton NG: Phosphorylation of amyloid-beta at the serine 26 residue by human cdc2 kinase. Neuroreport 2001, 12:3839-3844.

47. Kumar S, Rezaei-Ghaleh N, Terwel D, Thal DR, Richard M, Hoch M, Mc Donald JM, Wüllner U, Glebov K, Heneka MT, Walsh DM, Zweckstetter M, Walter J: Extracellular phosphorylation of the amyloid $\beta$-peptide promotes formation of toxic aggregates during the pathogenesis of Alzheimer's disease. EMBO J 2011, 30:2255-2265.

48. Kumar S, Wirths O, Theil S, Gerth J, Bayer TA, Walter J: Early intraneuronal accumulation and increased aggregation of phosphorylated $A \beta$ in a mouse model of Alzheimer's disease. Acta Neuropathol (Berl) 2013, 125:699-709.

49. Kumar S, Singh S, Hinze D, Josten M, Sahl H-G, Siepmann M, Walter J: Phosphorylation of amyloid- $\beta$ peptide at serine 8 attenuates its clearance via insulin-degrading and angiotensin-converting enzymes. J Biol Chem 2012, 287:8641-8651.

50. Radi R, Cassina A, Hodara R, Quijano C, Castro L: Peroxynitrite reactions and formation in mitochondria. Free Radic Biol Med 2002, 33:1451-1464.

51. Butterfield DA, Reed TT, Perluigi M, De Marco C, Coccia R, Keller JN, Markesbery WR, Sultana R: Elevated levels of 3-nitrotyrosine in brain from subjects with amnestic mild cognitive impairment: implications for the role of nitration in the progression of Alzheimer's disease. Brain Res 2007, 1148:243-248.

52. Castegna A, Thongboonkerd V, Klein JB, Lynn B, Markesbery WR, Butterfield DA: Proteomic identification of nitrated proteins in Alzheimer's disease brain. J Neurochem 2003, 85:1394-1401.

53. Heneka MT, Wiesinger $H$, Dumitrescu-Ozimek L, Riederer P, Feinstein DL, Klockgether T: Neuronal and glial coexpression of argininosuccinate synthetase and inducible nitric oxide synthase in Alzheimer disease. $J$ Neuropathol Exp Neurol 2001, 60:906-916.

54. Vodovotz Y, Lucia MS, Flanders KC, Chesler L, Xie QW, Smith TW, Weidner J, Mumford R, Webber R, Nathan C, Roberts AB, Lippa CF, Sporn MB: Inducible nitric oxide synthase in tangle-bearing neurons of patients with Alzheimer's disease. J Exp Med 1996, 184:1425-1433.

55. Kummer MP, Hermes M, Delekarte A, Hammerschmidt T, Kumar S, Terwel D, Walter J, Pape H-C, König S, Roeber S, Jessen F, Klockgether T, Korte M, Heneka MT: Nitration of tyrosine 10 critically enhances amyloid $\beta$ aggregation and plaque formation. Neuron 2011, 71:833-844.

56. Al-Hilaly YK, Williams TL, Stewart-Parker M, Ford L, Skaria E, Cole M, Bucher WG, Morris KL, Sada AA, Thorpe JR, Serpell LC: A central role for dityrosine crosslinking of amyloid- $\beta$ in Alzheimer's disease. Acta Neuropathol Commun 2013, 1:83. 
57. Thiabaud G, Pizzocaro S, Garcia-Serres R, Latour J-M, Monzani E, Casella L: Heme binding induces dimerization and nitration of truncated $\beta$-amyloid peptide $A \beta 16$ under oxidative stress. Angew Chem Int Ed Engl 2013, 52:8041-8044.

58. Halim A, Brinkmalm G, Rüetschi U, Westman-Brinkmalm A, Portelius E, Zetterberg H, Blennow K, Larson G, Nilsson J: Site-specific characterization of threonine, serine, and tyrosine glycosylations of amyloid precursor protein/amyloid beta-peptides in human cerebrospinal fluid. Proc Nat Acad Sci USA 2011, 108:11848-11853.

59. Mori H, Takio K, Ogawara M, Selkoe DJ: Mass spectrometry of purified amyloid beta protein in Alzheimer's disease. J Biol Chem 1992 267:17082-17086.

60. Saido TC, Iwatsubo T, Mann DM, Shimada H, Ihara Y, Kawashima S: Dominant and differential deposition of distinct beta-amyloid peptide species, ABN3(pE), in senile plaques. Neuron 1995, 14:457-466.

61. Sevalle J, Amoyel A, Robert P, Fournié-Zaluski M-C, Roques B, Checler F: Aminopeptidase $\mathrm{A}$ contributes to the $\mathrm{N}$-terminal truncation of amyloid beta-peptide. J Neurochem 2009, 109:248-256.

62. Liu K, Solano I, Mann D, Lemere C, Mercken M, Trojanowski JQ, Lee VM-Y: Characterization of A $\beta 11-40 / 42$ peptide deposition in Alzheimer's disease and young Down's syndrome brains: implication of N-terminally truncated $A \beta$ species in the pathogenesis of Alzheimer's disease. Acta Neuropathol (Berl) 2006, 112:163-174.

63. Huse JT, Liu K, Pijak DS, Carlin D, Lee VM-Y, Doms RW: Beta-secretase processing in the trans-Golgi network preferentially generates truncated amyloid species that accumulate in Alzheimer's disease brain. J Biol Chem 2002, 277:16278-16284.

64. Liu K, Doms RW, Lee VM-Y: Glu11 site cleavage and N-terminally truncated $A \beta$ production upon BACE overexpression. Biochemistry (MosC) 2002, 41:3128-3136.

65. Schilling S, Hoffmann T, Manhart S, Hoffmann M, Demuth H-U: Glutaminyl cyclases unfold glutamyl cyclase activity under mild acid conditions. FEBS Lett 2004, 563:191-196.

66. Schilling S, Zeitschel U, Hoffmann T, Heiser U, Francke M, Kehlen A, Holzer M, Hutter-Paier B, Prokesch M, Windisch M, Jagla W, Schlenzig D, Lindner C, Rudolph T, Reuter G, Cynis H, Montag D, Demuth H-U, Rossner S: Glutaminyl cyclase inhibition attenuates pyroglutamate $A \beta$ and Alzheimer's disease-like pathology. Nat Med 2008, 14:1106-1111.

67. Cynis $H$, Scheel E, Saido TC, Schilling S, Demuth H-U: Amyloidogenic processing of amyloid precursor protein: evidence of a pivotal role of glutaminyl cyclase in generation of pyroglutamate-modified amyloid-beta. Biochemistry (Mosc) 2008, 47:7405-7413.

68. Jawhar S, Wirths O, Schilling S, Graubner S, Demuth H-U, Bayer TA Overexpression of glutaminyl cyclase, the enzyme responsible for pyroglutamate $A \beta$ formation, induces behavioral deficits, and glutaminyl cyclase knock-out rescues the behavioral phenotype in 5XFAD mice. $J$ Biol Chem 2011, 286:4454-4460.

69. Tekirian TL, Yang AY, Glabe C, Geddes JW: Toxicity of pyroglutaminated amyloid beta-peptides $3(\mathrm{pE})-40$ and -42 is similar to that of $A \beta 1-40$ and -42. J Neurochem 1999, 73:1584-1589.

70. Youssef I, Florent-Béchard S, Malaplate-Armand C, Koziel V, Bihain B, Olivier J-L, Leininger-Muller B, Kriem B, Oster T, Pillot T: N-truncated amyloid- $\beta$ oligomers induce learning impairment and neuronal apoptosis. Neurobiol Aging 2008, 29:1319-1333.

71. He W, Barrow CJ: The Aß3-pyroglutamyl and 11-pyroglutamyl peptides found in senile plaque have greater beta-sheet forming and aggregation propensities in vitro than full-length A . Biochemistry (Mosc) 1999, 38:10871-10877.

72. Christensen DZ, Kraus SL, Flohr A, Cotel M-C, Wirths O, Bayer TA: Transient intraneuronal $A \beta$ rather than extracellular plaque pathology correlates with neuron loss in the frontal cortex of APP/PS1KI mice. Acta Neuropathol (Berl) 2008, 116:647-655.

73. Kawarabayashi T, Younkin LH, Saido TC, Shoji M, Ashe KH, Younkin SG: Age-dependent changes in brain, CSF, and plasma amyloid $\beta$ protein in the Tg2576 transgenic mouse model of Alzheimer's disease. J Neurosci 2001, 21:372-381.

74. Wirths $\mathrm{O}$, Breyhan $\mathrm{H}$, Cynis $\mathrm{H}$, Schilling $\mathrm{S}$, Demuth $\mathrm{H}-\mathrm{U}$, Bayer TA Intraneuronal pyroglutamate-A $\beta$ 3-42 triggers neurodegeneration and lethal neurological deficits in a transgenic mouse model. Acta Neuropathol (Berl) 2009, 118:487-496.
75. Alexandru A, Jagla W, Graubner S, Becker A, Bäuscher C, Kohlmann S, Sedlmeier R, Raber KA, Cynis H, Rönicke R, Reymann KG, Petrasch-Parwez E, Hartlage-Rübsamen M, Waniek A, Rossner S, Schilling S, Osmand AP, Demuth H-U, von Hörsten S: Selective hippocampal neurodegeneration in transgenic mice expressing small amounts of truncated $A \beta$ is induced by pyroglutamate-A $\beta$ formation. J Neurosci Off J Soc Neurosci 2011, 31:12790-12801.

76. Szendrei Gl, Fabian H, Mantsch HH, Lovas S, Nyéki O, Schön I, Otvos L Jr: Aspartate-bond isomerization affects the major conformations of synthetic peptides. Eur J Biochem FEBS 1994, 226:917-924.

77. Roher AE, Lowenson JD, Clarke S, Wolkow C, Wang R, Cotter RJ, Reardon IM, Zürcher-Neely HA, Heinrikson RL, Ball MJ: Structural alterations in the peptide backbone of beta-amyloid core protein may account for its deposition and stability in Alzheimer's disease. J Biol Chem 1993, 268:3072-3083.

78. Fabian H, Szendrei Gl, Mantsch HH, Greenberg BD, Otvös L Jr: Synthetic post-translationally modified human $A \beta$ peptide exhibits a markedly increased tendency to form beta-pleated sheets in vitro. Eur J Biochem FEBS 1994, 221:959-964.

79. Shimizu T, Fukuda H, Murayama S, Izumiyama N, Shirasawa T: Isoaspartate formation at position 23 of amyloid beta peptide enhanced fibril formation and deposited onto senile plaques and vascular amyloids in Alzheimer's disease. J Neurosci Res 2002, 70:451-461.

80. Fukuda H, Shimizu T, Nakajima M, Mori H, Shirasawa T: Synthesis, aggregation, and neurotoxicity of the Alzheimer's A $\beta 1-42$ amyloid peptide and its isoaspartyl isomers. Bioorg Med Chem Lett 1999, 9:953-956.

81. Kuo YM, Webster S, Emmerling MR, De Lima N, Roher AE: Irreversible dimerization/tetramerization and post-translational modifications inhibit proteolytic degradation of $A \beta$ peptides of Alzheimer's disease. Biochim Biophys Acta 1998, 1406:291-298.

82. Fonseca MI, Head E, Velazquez P, Cotman CW, Tenner AJ: The presence of isoaspartic acid in $\beta$-amyloid plaques indicates plaque age. Exp Neurol 1999, 157:277-288

83. Iwatsubo T, Saido TC, Mann DM, Lee VM, Trojanowski JQ: Full-length amyloid-beta (1-42(43)) and amino-terminally modified and truncated amyloid-beta 42(43) deposit in diffuse plaques. Am J Pathol 1996, 149:1823-1830.

84. Kubo T, Kumagae Y, Miller CA, Kaneko I: Beta-amyloid racemized at the Ser26 residue in the brains of patients with Alzheimer disease: implications in the pathogenesis of Alzheimer disease. J Neuropathol Exp Neurol 2003, 62:248-259.

85. Tomiyama T, Asano S, Furiya Y, Shirasawa T, Endo N, Mori H: Racemization of Asp23 residue affects the aggregation properties of Alzheimer amyloid beta protein analogues. J Biol Chem 1994, 269:10205-10208.

86. Tambo K, Yamaguchi T, Kobayashi K, Terauchi E, Ichi I, Kojo S: Racemization of the aspartic acid residue of amyloid- $\beta$ peptide by a radical reaction. Biosci Biotechnol Biochem 2013, 77:416-418.

87. Inoue K, Hosaka D, Mochiuki N, Akatsu H, Tsutsumiuchi K, Hashizume Y, Matsukawa N, Yamamoto T, Toyo'oka T: Simultaneous determination of post-translational racemization and isomerization of $\mathrm{N}$-terminal amyloid-beta in Alzheimer's brain tissues by covalent chiral derivatized ultra-performance liquid chromatography tandem mass spectrometry. Anal Chem 2013, 86:797-804.

88. Portelius $\mathrm{E}$, Gustavsson MK, Zetterberg $\mathrm{H}$, Andreasson U, Blennow K: Evaluation of the performance of novel $A \beta$ isoforms as theragnostic markers in Alzheimer's disease: from the cell to the patient. Neurodegener Dis 2012, 10:138-140.

89. Welge V, Fiege O, Lewczuk P, Mollenhauer B, Esselmann H, Klafki H-W, Wolf S, Trenkwalder C, Otto M, Kornhuber J, Wiltfang J, Bibl M: Combined CSF tau, p-tau181 and amyloid-beta 38/40/42 for diagnosing Alzheimer's disease. J Neural Transm Vienna Austria 1996 2009, 116:203-212.

90. Bibl M, Mollenhauer B, Lewczuk P, Esselmann H, Wolf S, Otto M, Kornhuber J, Rüther E, Wiltfang J: Cerebrospinal fluid tau, p-tau 181 and amyloid- $\beta 38 / 40 / 42$ in frontotemporal dementias and primary progressive aphasias. Dement Geriatr Cogn Disord 2011, 31:37-44.

91. Britschgi M, Olin CE, Johns HT, Takeda-Uchimura Y, LeMieux MC, Rufibach K, Rajadas J, Zhang H, Tomooka B, Robinson WH, Clark CM, Fagan AM, Galasko DR, Holtzman DM, Jutel M, Kaye JA, Lemere CA, Leszek J, Li G, Peskind ER, Quinn JF, Yesavage JA, Ghiso JA, Wyss-Coray T: Neuroprotective natural antibodies to assemblies of amyloidogenic peptides decrease with 
normal aging and advancing Alzheimer's disease. Proc Natl Acad Sci USA 2009, 106:12145-12150.

92. Marcello A, Wirths O, Schneider-Axmann T, Degerman-Gunnarsson M, Lannfelt L, Bayer TA: Reduced levels of IgM autoantibodies against $\mathrm{N}$-truncated pyroglutamate $A \beta$ in plasma of patients with Alzheimer's disease. Neurobiol Aging 2011, 32:1379-1387.

93. Sullivan CP, Berg EA, Elliott-Bryant R, Fishman JB, McKee AC, Morin PJ, Shia $M A$, Fine RE: Pyroglutamate- $A \beta 3$ and 11 colocalize in amyloid plaques in Alzheimer's disease cerebral cortex with pyroglutamate-A $\beta 11$ forming the central core. Neurosci Lett 2011, 505:109-112.

\subsection{6/alzrt258}

Cite this article as: Kummer and Heneka: Truncated and modified amyloid-beta species. Alzheimer's Research \& Therapy 2014, 6:28 